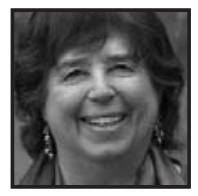

\title{
Commentary: Writing Picture Books
}

\author{
Jane Yolen
}

\begin{abstract}
In this interview Jane Yolen, award-winning author of children's picture books, talks of how her books come into being and the sometimes long period between the first spark of an idea and the time writing begins. She explains the many types of research that can be required for different types of books, giving examples from her own work. She also provides insight as to the role of the writer, the illustrator and the editor in creating the final version of a children's picture book. Finally, she reveals her own favourite children's picture books and gives advice to those wishing to write in this genre.
\end{abstract}

The theme of this issue of LEARNing Landscapes is "inquiry" and we're trying to get as many different perspectives on how people do inquiry. We thought it would be both interesting and inspiring to hear from an eminent author such as yourself and to learn how you go about creating a book. Can you describe the process you engage in from the onset of the idea or question until the work is completed?

\footnotetext{
Jometimes the time between when you get an idea and when you actually figure out where to go with it may be years, even in a picture book. "Owl Moon," for example, was based on my husband's taking our children owling and I knew I wanted to write about that but from the moment I knew I wanted to write about it until I actually started sitting down and writing something that looks like "Owl Moon" was probably about 15,20 years. So sometimes there's this encysting of a pearl, but it takes more time than anybody knows about except the writer. So that's a hard question to answer.
} 
Can you say a little bit about the ingredients that go into the process even if it's over a long period of time?

Well, first of all there has to be a moment when something real-and I don't mean it has to be actual. It has to be real inside the writer and that connects with an emotion. So, an element of the story has to connect with an emotion and that's when - for me at any rate-everything starts to come together. For example, I had the idea of a father taking a child owling, that was the idea but I needed the emotional grounding, the base of what the story was going to be about. Interestingly enough it didn't come together for me until my children were grown and two, I was not at that moment living in the U.S. next to the Owl Moon Woods, I was [living] in Scotland. It's almost as if I needed distance from both the children and the place to see it more clearly. Now that doesn't always happen. Sometimes a picture book comes whole cloth. A book such as "How Do Dinosaurs Say Good Night?" was a whole-cloth book. But with "Owl Moon" I needed that kind of distance, a kind of recollection in tranquility of the particular memory that became so strong and so powerful inside of me that I turned it into a story. So then it was no longer just a memory, but a story.

Of course there are other things that go on when you're writing a picture book. When I teach picture book writing to students I say that there are ten words that every picture book writer needs and that you must keep clear in your thoughts, even if not thinking about them every moment. Those ten words are lyricism, compression, child-centeredness, focus, hook, words (because we don't dumb down the words, we use the right words), illustratability (key in picture books, you have to write something that can be illustrated). And then, as in any other kind of writing, there has to be motion, emotion, resolution. So those are the ten words that I tell them. The difference most clearly when you're writing a picture book is the illustratability because [in] other kinds of writing - though you need lyricism and some sort of compression, especially if you're doing poetry, and child-centeredness if you're doing any kind of children's books whether they're for young children or middle-grade children-it's that illustratability that's key for the picture book.

\section{What kind of research do you carry out to pull together the ideas for a book?}

Well, it depends on the kind of book of course. If it has a historical basis you're going to do historical research. For "Owl Moon,"I had my husband right there. He was very well considered within the birding community and so I could check with 
him: what would you be doing in the wild? What does a Grey Horned owl sound like? That sort of thing. I'd gone out owling with him, had heard owls calling. We had more books in the house about birds and birdcalls and what else is going to be out in the winter woods than you could shake a stick at. So even if he hadn't been around I could have done my research easily. But let me mention three other picture books that I've done recently. One is the dinosaur books. There's not a lot of research in those books. They're bouncy and rollicking. The research, if you think about it, has to do with what issues do we want to attend to in the next dinosaur book. Do we want to deal with anger, do we want to deal with birthdays, do we want to deal with how to treat your cat or your dog. So talking it over with the editor is really the research there, about what things we want to pinpoint within the book. Then I did a picture book called "All Star" which is about the life of Honus Wagner, the great shortstop in the early days of baseball. That needed a tremendous amount of research. I read about four, five or six books on Honus Wagner and more on early baseball in order to write, oh, I don't know, 1800 words? Because you had to know as much as you could possibly know in order to bring it to the lyrical level and still be talking about Honus Wagner. The third picture book that I want to mention is a picture book that J. Patrick Lewis and I did, in poems, that's coming out, about the life of Chagall. So again we had to read books, we had to look at his paintings because we were tying each poem to one of Chagall's pictures but also to his life. So we were doing research both in his life, in Vitebsk where he came from and his early life in the old country, then during the time of the Nazis and what happened to him there... but also, as much as we could read about his life, we also were reading about his art. So those are just three possible ways where research comes in to writing picture books, but in very different ways.

Obviously the final representation of a book as an author is particularly important. What are the kinds of things that you consider when you are putting your book together in its final form?

First of all you have to understand that only very, very rarely does an author get to choose an illustrator. This is the provenance of the editor and the art director at the publishing company. Now, they will consult with you, they will [tell] you, "We were thinking of so-and-so" or "Here are five illustrators that we've been considering." You may have talked ahead of time with them about the kind of art, you may even have suggested a couple of illustrators to them. But none of that guarantees they will choose any of those illustrators. So, remembering that, the next step is that the writer will probably be sent sketches, especially if it's technical stuff. For Honus Wagner I sent a couple of the books I was using for research to illustrator James Burke because 
there were some interesting photographs and memorabilia in it that I thought he might be able to use for the pictures. If something is technically wrong — say you say in the book, "She raised her right hand and waved at the owl" and the picture shows her waving her left hand at a crow-then you have a problem. There are two ways to solve that problem. If the pictures are only in sketch stage, the illustrator can change it. If the illustrator has already finished the picture, the writer has to decide: "Is it important for her to raise her right hand or her left hand?"If it didn't matter, the writer can change it to the proper hand and proper bird. However if it matters that it's an owl and not a crow then you have a further problem. Either the illustrator has to reillustrate which is a long and laborious process or you have to find another way around it.

Can you give us maybe four or five key things that you would look for in a final picture book that would set it up as an interesting and exciting type of inquiry that has reached fruition?

I'm not quite sure I understand the question because once I've finished the manuscript and it's been revised for the editor, and once the illustrator has done his/her magic, and perhaps I've done some more revisions in order to have the two connect in a more interesting or better or more compressed fashion, I'm done with the book. I can look at it and say, "This book has won the Caldecott, I love this book." Or, "Oh my gosh, I loved this book and it sank in six months." If a book wins a prize or doesn't win a prize or it doesn't do well it does not necessarily mean it's good or bad, because that's in the hands of the gods, that's fairy dust. There's no way that an author can really influence that. You can get out there, you can sign books, you can talk to people, you can write about the book on-line, do bookstore events, but in the end the writer really cannot influence what happens to the book, how it is seen, how it is used in classrooms, whether the book becomes a hit.

I wonder, if you were a judge of a book, what kinds of things you would be looking for?

Shall I tell you some of my favourite picture books - I mean not any of mine but in general? I loved "Where the Wild Things Are" and "In the Night Kitchen"; I love a book by Barbara Berger called, "Grandfather Twilight"; I love a book by Florence Parry Heide, "Princess Hyacinth: The Surprising Tale of a Girl Who Floated"; I love a recent book by Lane Smith called, "It's a Book." I like witty books, I love beautifully 
written and illustrated books, I love books that make me laugh and books that make me weep. I don't like the endless repetition of the same kind of "I love you" books; I don't like the fart books and the poop books that are coming out now. I just find them distressing. But that's very old-fashioned of me.

Finally what suggestions do you have for authors about doing the research or travelling the journey that is required for creating a book, a thesis, a research project?

The first thing for anyone who wants to do a book for children is to sit down, and for several months do nothing but read books for children. Read the ones you remember from your own childhood and then read the ones that are winning the awards now, and the ones that are the best sellers now. Because you don't want to keep reinventing the wheel. That's the first thing. That's the first basic research that anyone should do who wants to get in on this. This is why I hate it when celebrities come in and they say, "Oh, I can't find any good books for children so I'm going to write one," which just means they haven't read anything.

Next, it depends on what kind of book you're doing as to where you are going to go for the research or the research element of that book. Again, if the book is historical, you may visit where it took place. If it's a book about emotional content, you're going to go research somewhere else for that. Perhaps, go inside yourself, or your children or your grandchildren or your neighbour's children to find out about that emotional moment. If you are writing a book that seems straightforward but then realize you don't know, for example, what animals would be out in the winter time or, what songs the birds would sing as you're walking along, or what trees are in bloom as the child is going on a spring visit to grandma's, then you need to find out. There are things that we take for granted, but once writing them down, the author needs to find out if they are true. If I have someone tromping through the woods and stepping on flowers in the springtime and the flowers I have chosen are fall flowers, that's a big mistake. I certainly don't want to send the story off to an editor, who may live in New York and may not know any better than I do about spring flowers. If I'm retelling a fairy tale, I need to make sure it's an old tale, not a new tale that someone else has told or written for the first time. If I want to quote a line of poetry or song lyrics, I may need to get permission, so that's another kind of research. There are all kinds of research pitfalls that the writer may fall into, even when writing something as short and as compressed as a picture book. 


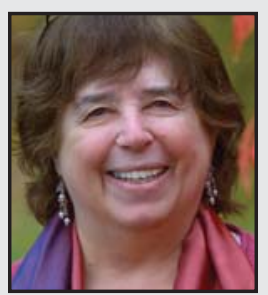

Photo credit:

OJason Stemple
Jane Yolen, often called "the Hans Christian Andersen of America," is the author of over 300 published books, including "Owl Moon," "The Devil's Arithmetic," and "How Do Dinosaurs Say Good Night?". The books range from rhymed picture books and baby board books, through middle grade fiction, poetry collections, nonfiction, and up to novels and story collections for young adults and adults. She has won two Nebulas, a World Fantasy Grand Master Award, and been named a Grand Master of sf/fantasy poetry by SFPA, the Science Fiction Poetry Association. Six colleges and universities have given her honorary doctorates.

\section{LINK TO:}

www.janeyolen.com 